\title{
REPRODUCTIVE ECOLOGY OF AEGIALITIS ROTUNDIFOLIA ROXB., A CRYPTO-VIVIPAROUS MANGROVE PLANT SPECIES IN KRISHNA MANGROVE FOREST, ANDRA PRADESH
}

Jacob Solomon Raju ALURI * and Henry Jonathan KARYAMSETTY *

* Andhra University, Department of Environmental Sciences, Visakhapatnam, China Waltair Street, India, IN-530 003, solomonraju@gmail.com, khjonathan@gmail.com

DOI: 10.1515/trser-2018-0002

KEYWORDS: Crypto-vivipary, mixed breeding system, melittophily, India.

\section{ABSTRACT}

Aegialitis rotundifolia is a hermaphroditic, self-compatible species with mixed breeding system. The floral characters indicate melittophilous pollination syndrome. Field studies indicate this species is melittophilous but anemophily also occurs due to its seaward occurrence where high winds usually prevail. Autogamy and allogamy are functional, and these modes indicate a "fail-safe" strategy for reproductive assurance when con-specifics do not occur nearby. Natural fruit set rate is $55-61 \%$. The seed produces seedling within the fruit pericarp while it is still attached to the parent plant. Seedling or seed dispersal and establishment occurs through self-planting and stranding strategies.

ZUSAMMENFASSUNG: Reproduktionsökologie von Aegialitis rotundifolia Roxb., eine krypto-vivipare Pflanzenart im Krishna Mangrovenwald von Andhra Pradesh.

Aegialitis rotundifolia ist hermaphroditisch, selbstkompatibel mit einem gemischten Vermehrungssystem. Die floralen Kennzeichen weisen auf eine Neigung zu melittophiler Bestäubung hin. Feldstudien belegen diese Art als melittophil, aber es kann aufgrund ihres See seitigen Vorkommens, wo meist starke Winde vorherrschen auch anemophile Bestäubung stattfinden. Autogamie und Allogamie sind funktional und belegen eine "absolut sichere" Strategie für die Gewährleistung der Fortpflanzung, wenn keine Artgenossen in der Nähe auftreten. Die natürliche Fruchtungsrate beträgt 55-61\%. Die Samen produzieren Keimlinge innerhalb der Fruchtwand, während sie noch an der Stammpflanze hängen. Sämling oder Samen Ausbreitung und Etablierung findet durch Selbstpflanzung und Grundberührung statt.

REZUMAT: Ecologia reproducerii speciei Aegialitis rotundifolia Roxb., o plantă cripto-vivipară în pădurea de mangrove Krishna de la Andhra Pradesh.

Aegialitis rotundifolia este o specie hermafrodită, auto-compatibilă cu sistem mixt de reproducere. Caracterele florale indică sindromul de polenizare melitofilă. Studii de teren indică însă faptul că această specie este melitofilă, polenizarea efectuându-se și prin anemofilie datorită creșterii sale la marginea dinspre mare a mangrovei, unde prevalează în mod obișnuit vânturi puternice. Autogamia și alogamia sunt funcționale și aceste moduri indică o strategie „sigură în caz de avarie” pentru asigurarea reproducerii atunci când condominalele nu se întâlnesc în apropiere. Rata naturală de fructificare este de 55-61\%. Semințele produc germeni în pericarpul fructului în timp ce acesta este încă legat de planta mamă. Împrăştierea germenilor sau a semințelor are loc prin strategii de auto-plantare și de aderare la substrat. 


\section{INTRODUCTION}

Mangroves are one of the most interesting types of ecological systems in the world (Hogarth, 1999; Aziz and Hashim, 2011). Tomlinson (1986) was the first to describe the basic botany of mangroves. Floral biology accounts were based on floristic, biology, ecology, phytogeography, utilization and conservation of mangroves individually or in combination of them. Reproductive ecology studies of mangroves focused primarily on seed biology, especially viviparous and other seedling peculiarities. The study of pollination biology and breeding systems of mangroves in wetlands is a difficult task and hence the descriptions of pollination and breeding systems are almost exclusively based on floral characteristics without much or any experimentation. Chapman (1976) stated that the general opinion about mangroves is that the latter do not support a distinct pollinator fauna and the majority of animal pollinators recorded so far in them either come from the adjoining terrestrial vegetation or are characteristic of saline mud flats irrespective of whether they support a vegetation cover.

The genus Aegialitis (belonging to Aegialitidaceae family) is formed of two species, A. rotundifolia and A. annulata. The first one is present in Burma, Bengal, and the Andaman Islands; it occurs in exposed seaward sites. The second is present in northern Australia and east Malesia, but its characteristic sites of occurrence is not known. There is no information on the reproductive ecology of these two species (Tomlinson, 1986). The present reseach supply details of the reproductive ecology of Aegialitis rotundifolia Roxb. which is present in Krishna mangrove forest, Andhra Pradesh, India. The researched elements have been discussed in the light of main literature.

\section{MATERIALS AND METHODS}

The Krishna mangrove forest is located in the Krishna estuary in Krishna and Guntur districts, between $15^{\circ} 42^{\prime}-15^{\circ} 55^{\prime} \mathrm{N}$ and $80^{\circ} 42^{\prime}-81^{\circ} 01^{\prime} \mathrm{E}$ in the State of Andhra Pradesh, India. The total area of the Krishna mangrove forest is $140 \mathrm{~km}^{2}$ (State of Forest Report 2003 by Forest Survey of India, Dehradun, the Government of India). Aegialitis rotundifolia is a seaward euhaline crypto-viviparous mangrove plant species in the Krishna mangrove forest. It has a small population, far away from human habitations, and is unknown to locals. Field investigations and experiments were conducted during the period of August 2014 to August 2016.

Observations regarding the organization of inflorescences, the spatial positioning of flowers, and their position (terminal, axillary, etc.) on the trees were made, since these features are regarded as important for foraging and effecting pollination by flower-visitors. Quantification of the number of flowers produced per inflorescence was made. The duration of inflorescence life was determined by tagging 10 inflorescences which have not initiated flowering, selected at random and following them daily, until they ceased flowering permanently.

Anthesis was initially recorded by observing marked mature buds in the field. Later, the observations were repeated three to four times on different days in order to provide accurate anthesis schedule for each plant species. Similarly, the mature buds were followed for recording the time of anther dehiscence. The presentation pattern of pollen was also investigated by recording how anthers dehisced and confirmed by observing the anthers under a 10x hand lens. 
The flower morphology details, life-time and relative positions of stamens stigma from mature bud to the fall of flower through flower-opening for the possibility of self or crosspollination, were examined.

Twenty five mature buds prior anther dehiscence were collected from five plants and kept in a Petri dish. These buds were used for calculating pollen output per anther and flower, pollen-ovule ratio as per Cruden (1977). Pollen was collected again afresh from one hundred flowers, for the estimation of pollen protein content according to method provided by Lowry et al. (1951).

Stock standard of Bovine serum albumin (one mg/ml) was taken and $0.2 \mathrm{mg} / \mathrm{ml}$ of working standard was prepared. Serial dilutions of $0.2,0.4,0.6,0.8$ and one $\mathrm{ml}$ of protein solution were taken and the volume was made to one $\mathrm{ml}$ with distilled water. Then, two $\mathrm{ml}$ of alkaline copper solution was added to all these five different protein solutions and allowed to stand for 10 minutes. Then, $0.2 \mathrm{ml}$ of Folin-Ciocalteu's phenol reagent was added to each test tube and incubated for 30 minutes at laboratory temperature. A blank was prepared with one $\mathrm{ml}$ of distilled water and the absorbance was measured at $660 \mathrm{~nm}$. A standard curve was plotted by taking the protein concentration on $\mathrm{X}$-axis and absorbance on $\mathrm{Y}$-axis.

Ten flowers were used to determine the volume of nectar and it was measured in $\mu l$. Hand Sugar Refractometer was used to determine the nectar sugar concentration. Paper chromatography method of Harborne (1973) was used to carry out analysis of sugar types. The amount of sugar present in the nectar/flower was calculated as per the protocol provided in Dafni et al. (2005). Amino acids present in the nectar were qualitatively recorded using the Paper chromatography method described by Baker and Baker (1973).

The stigma receptivity was tested with hydrogen peroxide from mature bud stage to flower drop as per Dafni et al. (2005). $\mathrm{H}_{2} \mathrm{O}_{2}$ method described by Dafni et al. (2005) was used to test stigma receptivity duration.

Mature flower buds of some inflorescences on different individuals were tagged and enclosed in paper bags. They were tested in the following way and the number of flower buds used for each mode of pollination was given in the table.

1. The stigmas of flowers were pollinated with the pollen of the same flower manually by using a brush and bagged to observe manipulated autogamy.

2. The flowers were fine-mesh bagged as such without hand pollination to detect spontaneous autogamy.

3. The emasculated flowers were hand-pollinated with the pollen of a different flower on the same plant and bagged to test geitonogamy.

4. The emasculated flowers were pollinated with the pollen of a different individual and bagged to detect xenogamy.

5. The emasculated flowers were kept open without bagging for assessing the role of insects in pollination. Further, mature buds were bagged with coarse-mesh to prevent insects, but to permit wind to assess the role of wind in pollination. 
All these categories of flower pollinations were kept under regular observation until fruit set. Then, the percentage of fruit set was calculated for each mode. The flowers/inflorescences were tagged on different individuals prior to anthesis and followed for fruit and seed set rate in open-pollinations. The fruit and hypocotyl length, orientation, colour and other characteristics were also recorded. The importance of fruit pericarp in assisting hypocotyls/fruits for floating in water was also observed.

Foraging insects were observed at the flowers and identified to the extent possible. The insect species that were not identified were caught and identified by tallying the specimens of the study area already identified and deposited in the institution. The foraging visits made by each insect species at each hour on twenty flowering inflorescences were recorded for three consecutive days and the date pooled to calculate the relative percentage of visits made by them per day and total foraging visits made by each insect category per day. Ten specimens of each foraging insect species caught during peak foraging time were examined for the pollen carrying capacity of individual species. Each specimen was immersed and washed in ethyl alcohol and stained with aniline-blue on a glass slide prior to observation under microscope for pollen count. Further, foragers were observed for their flower probing behavior with reference to their role in pollination.

\section{RESULTS}

Phenology. It is a soft-wooded evergreen shrub species, growing to three $\mathrm{m}$ height, with a basally swollen fluted axis (Fig. 1a). It occurs in association with Ceriops decandra, $C$. tagal, Bruguiera gymnorrhiza and Excoecaria agallocha. Its' leaves excrete salt which, in turn, gets crystallized on the leaf surface on sunny days (Fig. 1b). The flowering occurs from 2nd week of February to 3rd week of April. An individual tree flowers for 20-22 days. The flowers are produced in terminal, irregular, one-sided cymes with pairs of opposite linear bracteoles. An inflorescence produces $6.2 \pm 1.6$ (Range 4-10) flowers over a period of six or seven days (Fig. 1c).

The Flower. Flowers are pedicellate, small, $18 \mathrm{~mm}$ long, $11 \mathrm{~mm}$ wide, white, cupshaped, odourless, bisexual, and zygomorphic. Sepals are five, small, nine mm long, green, united basally and free apically, glabrous, coriaceous, valvate and persistent. Petals are five, alternate to sepals, $12 \mathrm{~mm}$ long, white, herbaceous, free above with bluntly rounded lobes, and fused basally to form a corolla tube of three $\mathrm{mm}$ long. Stamens are five, $12 \mathrm{~mm}$ long, free, and inserted on the corolla tube alternately with the petals. The filaments are seven mm long, whitish, glabrous, slender, forming short hollow tube with a ring of internal and external hairs at the level of the mouth of the corolla tube. The anthers are bilobed, two $\mathrm{mm}$ long, inserted, sagittate, introrse and basifixed. Ovary is superior, oblong, one-chambered with a single basally attached anatropous ovule (Fig. 1o, q). It has five grooves each extending into a lobe which in turn extending into a free style (Fig. 1i). The styles are five, free, white, each style 10 $\mathrm{mm}$ long with an extended oblique peltate stigma initially facing inward and later facing outward (Fig. 1p). 


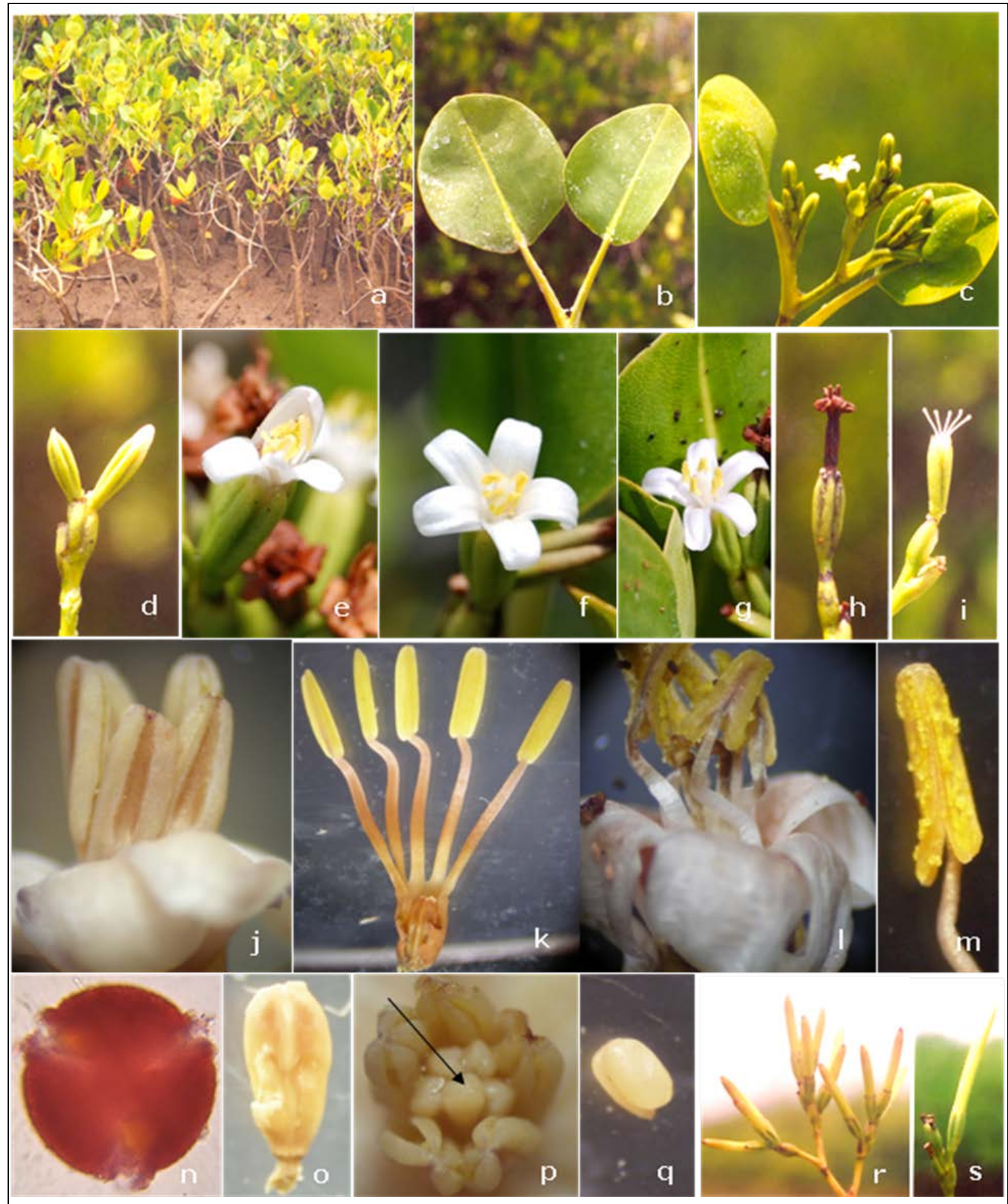

Figure 1: Aegialitis rotundifolia: a. Habitat; b. Leaves showing salt excreted from within the system; c. Flowering inflorescence; d. Buds; e-h. Different stages of flower life; i. Ovary with five free styles each terminated with a peltate stigma; $\mathrm{j}$. and $\mathrm{k}$. Undehisced anthers; $\mathrm{l}$. and $\mathrm{m}$.

Dehisced anthers; n. Pollen grain; o. Ovary; p. Free styles each terminated with a stigma; q. Single ovule; r. and s. Well developed propagules. 
Floral biology. The mature buds open at $07.00-09.30 \mathrm{~h}$ by slightly unfolding a single petal first, followed by the 2nd petal and other petals within two hours (Fig. 1d-f). Petals reflex backward partially exposing stamens and the styles (Fig. 1g). The styles and stigmas stand slightly below the height of the anthers, face inward at anthesis and diverge gradually moving away from the anthers but reaching closer to the petals. The anthers dehisce by longitudinal slits along with anthesis (Fig. 1j-m). The pollen output per anther is $288.6 \pm 40.27$ (Range 240372 ) and, per flower, is 1,443 . Pollen grains are large, spheroidal, tricolporate, characterized by prominent central wart-like sculptures, light yellow, exine rough, thick and $119.52 \pm 10.49$ $\mu \mathrm{m}$ in size (Fig. 1n). The pollen-ovule ratio is 1,443:1. The pollen protein content per anther is $6.08 \mu \mathrm{g}$ and per flower is $30.04 \mu \mathrm{g}$. Pollen grains are viable for $2^{1 / 2}$ days. The stigma attains receptivity two hours after anthesis and continues up to the evening of the 3rd day. A flower produces $6.50 \pm 0.8$ (Range 5-7.8) $\mu \mathrm{l}$ of nectar at the flower base by the time of anthesis. The nectar sugar concentration is $46.2 \pm 5.4 \%$ (Range $36-53 \%$ ) and the common sugars include fructose and glucose which occur in almost equal amounts. There is no significant correlation between nectar volume and sugar concentration $(r=-0.386$ at $\mathrm{p}>0.05$ significance level). The total sugar content in the nectar of a flower is $3.60 \pm 0.49$ (Range 3.07-4.64) mg. The nectar contains 16 amino acids which include tyrosine, glycine, lysine, aspartic acid, glutamic acid, serine, cysteine, cystine, alanine, threonine, arginine, phenylalanine, proline, tryptophan, valine, and histidine. The relative dominance of these amino acids is given in table 2. The corolla gradually turns from white to dark red from day one to day four. The dark red corolla, together with stamens and styles, remain in place for two to three weeks during which the calyx bulges due to growing fruit inside (Fig. 1h). The calyx is persistent and inseparable from fruit. The flowers not pollinated fall off on the 4th day.

Breeding system. The results of breeding systems indicate that the flowers are self-compatible and self-pollinating. The fruit set is $9 \%$ in wind-pollinated flowers, $25 \%$ in spontaneous autogamy, $47 \%$ in insect-assisted pollination, and $60 \%$ in open pollination (Tab. 1). Fruit set per inflorescence in open pollination is $2.62 \pm 1.41$ (Range 1-7).

Table 1: Results of breeding experiments on Aegialitis rotundifolia.

\begin{tabular}{|l|l|l|c|c|}
\hline \multicolumn{1}{|c|}{ Test } & \multicolumn{1}{|c|}{ Treatment } & \multicolumn{1}{|c|}{ Pollen source } & $\begin{array}{c}\text { No. of } \\
\text { flowers/plants }\end{array}$ & $\begin{array}{c}\text { Fruit set } \\
(\%)\end{array}$ \\
\hline Control & Unbagged & Open pollination & $300 / 30$ & 60 \\
\hline $\begin{array}{l}\text { Wind } \\
\text { pollination }\end{array}$ & $\begin{array}{l}\text { Coarse-mesh } \\
\text { bagged }\end{array}$ & $\begin{array}{l}\text { The same flower or } \\
\text { other flowers } \\
\text { transported by wind }\end{array}$ & $100 / 10$ & 9 \\
\hline $\begin{array}{l}\text { Spontaneous } \\
\text { autogamy }\end{array}$ & $\begin{array}{l}\text { Fine-mesh } \\
\text { bagged }\end{array}$ & The same flower & $240 / 20$ & 25 \\
\hline $\begin{array}{l}\text { Insect-assisted } \\
\text { cross- } \\
\text { pollination }\end{array}$ & $\begin{array}{l}\text { Unbagged, } \\
\text { emasculated }\end{array}$ & $\begin{array}{l}\text { Other flowers on the } \\
\text { same or different } \\
\text { plants }\end{array}$ & $100 / 10$ & 47 \\
\hline
\end{tabular}


Pollination mechanism and pollinators. The flowers are not specialized, but the sex organs get exposed when the petals partially reflex downwards. Foraging bees consisting of Apis dorsata, A. cerana, A. florea and Ceratina simillima collected both pollen and nectar throughout the day (Fig. 2), with more activity during forenoon time effecting pollination. $A$. dorsata and A. florea collectively made more than $60 \%$ of total foraging visits (Fig. 3). All bee species were found to carry pollen, but the amount of pollen varied with each species (Tab. 2). High winds blow regularly seaside and cause the pollen grains to be released by anthers in air.

Table 2: Pollen carrying capacity of insect foragers of Aegialitis rotundifolia.

\begin{tabular}{|c|c|c|c|}
\hline Insect species & Sample size & Range & Mean \pm S.D. \\
\hline Apis dorsata & 10 & $132-1,152$ & $658 \pm 316.94$ \\
\hline Apis cerana & 10 & $59-147$ & $96.3 \pm 30.35$ \\
\hline Apis florea & 10 & $22-184$ & $78.4 \pm 62.6$ \\
\hline Ceratina simillima & 10 & $15-42$ & $24.7 \pm 8.65$ \\
\hline
\end{tabular}

Fruiting behaviour. Pollinated and fertilized flowers initiate fruit development immediately and take 30-45 days to produce mature fruits. The fruit is an elongated, bluntly pointed one-seeded capsule, light green to brown, $72 \pm 4 \mathrm{~mm}$ (Range 65-83) long, enveloped basally by persistent calyx, funicular tube attached to seed and enlarging hypocotyl which protrudes from the seed coat but not the pericarp. The seed coat is hard, brown, embryo elongated with an extended hypocotyl. Mature fruit with well developed hypocotyl stands upright (Figs. 1r, s). The fruit pericarp is thin but thickened somewhat distally. It is waterbuoyant and dispersed by tidal waters. It detaches along with the quadrangular calyx. The hypocotyls settle at the mother plant if the site is not inundated due to tidal water and float in tidal waters, especially during high tide periods. In fruits that float in tidal waters, the pericarp becomes soft and ruptures longitudinally to expose the hypocotyl to saline water. The hypocotyls devoid of fruit pericarp did not float, while those with it floated. Such hypocotyls float until they find suitable substratum which is sticky and silty mud. The radicle side of hypocotyl penetrates the soil and produces root system while plumule side produces new leaves and subsequent aerial system. In the study area, very few propagules were found to settle, establish and produce new plants. 


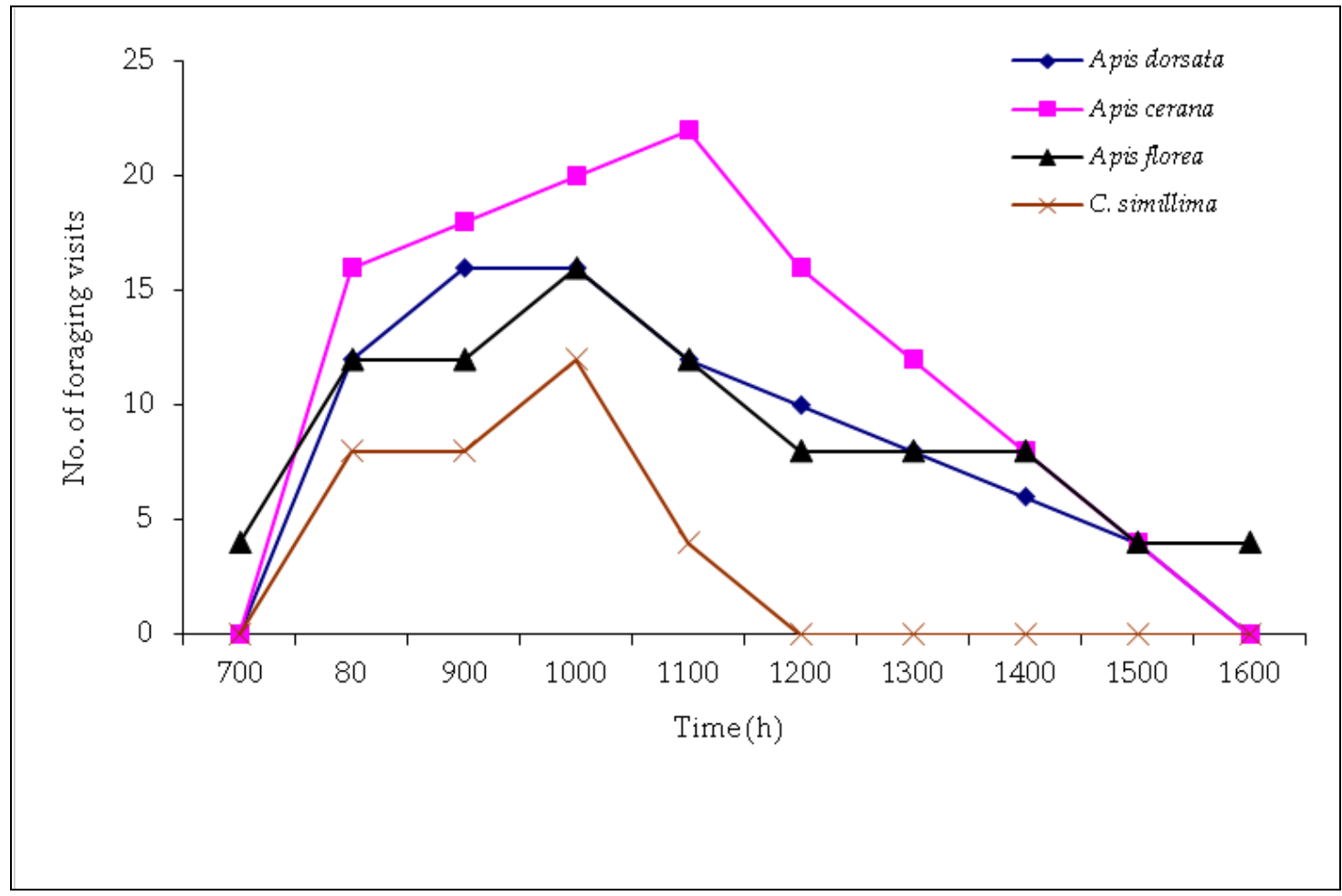

Figure 2: Hourly foraging activity of bees on Aegialitis rotundifolia.

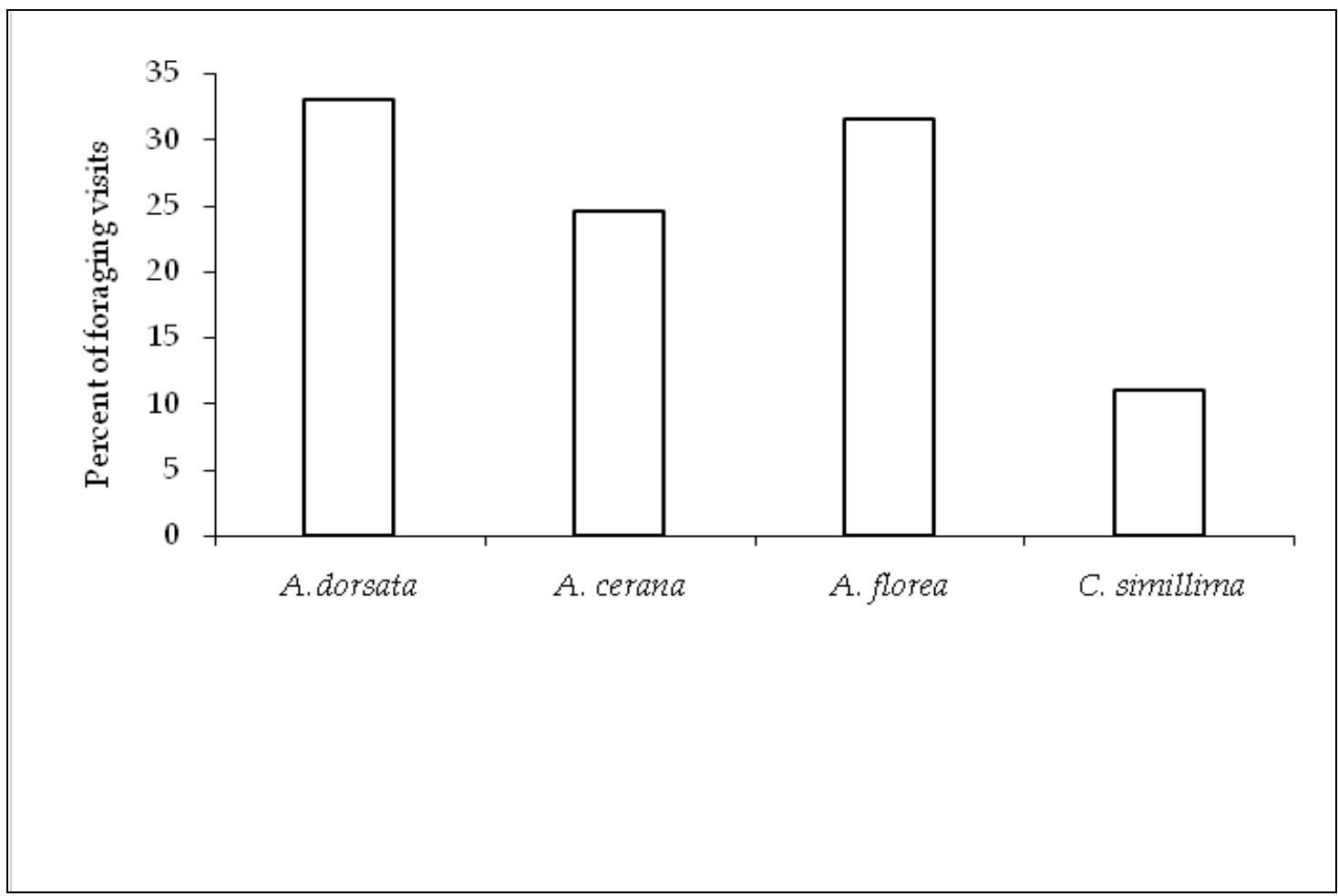

Figure 3: Percentage of foraging visits of bees on Aegialitis rotundifolia. 


\section{DISCUSSION}

Distribution, salt excretion and floral characteristics. The genus Aegialitis represents only two shrub species, A. annulata and A. rotundifolia. It is recently segregated as the family Aegialitidaceae because of some distinctive features from other genera of Plumbaginaceae. Some features include anomalous secondary thickening, abundant sclereids, incipiently viviparous seeds, monomorphic pollen, and homostylous flowers (Weber-El Ghobary, 1984; Tomlinson, 1986). The two species do not occur together in the same forest and have distribution in different parts of the world. A. annulata is distributed in Australia and eastern Malaysia (Tomlinson, 1986) while A. rotundifolia in South Africa and South-East Asia (Kathiresan and Bingham, 2001). A. rotundifolia has been reported to occur in Burma, Bengal and the Andamans by Tomlinson (1986). Later, Naskar and Mandal (1999) reported this species as occurring in the Sundarbans, Andaman and Nicobar Islands and Mahanadi delta of Orissa only. Ramasubramanian et al. (2003) have not mentioned the occurrence of $A$. rotundifolia in their recently published book on the mangrove flora of Krishna and Godavari deltas of Andhra Pradesh. The present study revealed the presence of A. rotundifolia in Nachugunta Reserve Forest of Krishna Mangroves in Andhra Pradesh and, hence, it is the first record of $A$. rotundifolia from Andhra Pradesh.

Tomlinson (1986) stated that the Aegialitis species prefer or require exposed sites and withstand waves and tidal action. Further, he also mentioned that A. rotundifolia does not occur within closed mangrove communities, but it may occur as back mangal if soil is highly saline. Aksornkoae et al. (1992) also reported similarly about the habitat requirements of $A$. rotundifolia. Also, at the study site, this species occurs in seaward, euhaline and exposed sites.

As the habitat of $A$. rotundifolia is highly saline, salt in high concentrations in plant tissues is toxic and hence, must be excluded by some mechanism. The absorbed salt is excreted metabolically via salt glands present on the leaf blade (Scholander, 1968). The salt evaporates or crystallizes in a conspicuous manner on the surface of leathery leaf blades of $A$. rotundifolia. Later, the crystallized salt blows away or washes off during cool period by the absorption of atmospheric moisture and by rain. Therefore, A. rotundifolia with salt excretion mechanism is highly specialized to withstand high saline soils.

Naskar and Mandal (1999) reported that the ovary is five-carpelled, syncarpous and stigma is absent in A. rotundifolia. But, in the present study, it is found that the ovary is onechambered, styles five each terminated with an extended oblique peltate stigma as reported by Tomlinson (1986). Weber-El Ghobary (1984) reported that distinct monomorphic pollen is the characteristic feature in this species, and also in A. annulata. This study confirms the same.

Pollination biology. The plant is a dry season bloomer but it completes flowering prior to the onset of extreme dry conditions in the month of May. During this period, fluvial discharge from rivers to sea is almost negligible and this would result in increased salinity of seawater. A steep increase in salinity levels can be expected at the site of the plant which is characteristically seaward in occurrence. Increased salinity of seawater reportedly prevents fruiting and causes senescence of immature flowers and buds (Qureshi, 1993). This may be an important factor for the plant to cease flowering by the mid-April and supply the available resources to the growing fruits to realize maximum fruit set.

A. rotundifolia with anthesis during morning hours and odourless flowers indicates that it is adapted for pollination during daytime. The floral characteristics of this plant, such as short-tubed corolla with anthers at the flower entrance, the styles and stigmas situated slightly 
below the anthers, production of slightly moderate volume of nectar with high sugar concentration and presence of only hexose sugars in nectar, are adaptations for bee-pollination (Baker and Baker, 1983; Opler, 1983). Further, the nectar has the essential amino acids such as arginine, lysine, phenylalanine, threonine, tryptophan, valine and histidine, and also some nonessential amino acids. De Groot (1953) showed that insects in general and honeybees in particular require ten essential amino acids, and seven of them are present in the nectar of this plant. The pollen also has some protein content. The flower visitors recorded are exclusively honeybees and stingless bees; the latter are also honey producers. These bees collect both pollen and nectar from the flowers. They carry pollen on their bodies and pollinate the flowers while probing for the forage. As they require more quantity of forage for honey production and brood rearing, they collect forage from as many flowers as available on A. rotundifolia and hence, contribute to both self- and cross-pollination. Naskar and Mandal (1999) mentioned that this plant is pollinated by the honey bee, Apis dorsata in the Sundarban mangroves. Bhattacharya et al. (2006) also noted that the pollen of this plant is dominant in honey collected from the Sundarbans region. Therefore, A. rotundifolia is primarily melittophilous.

A. rotundifolia flowers are weakly protandrous, self-compatible and self-pollinating. The protandry does not contribute to autogamy in the first two hours of flower life as the stigmas lack receptivity during that period. Gradually, the stigmas diverge and stand away from the anthers while they attain receptivity to pollen. Individual flowers with this situation produce fruit through autogamy with the aid of wind or honeybees. The pollen grains are very large and fall down on the stigmas gravitationally due to wind action, the result of which is autogamy. If there are flowers of the same age, side by side in the same or adjacent inflorescences, geitonogamy may occur. However, the flower function with reference to protandry, movement of stigmas, and duration of stigma receptivity suggests that the plant is primarily evolved for outcrossing. Hand-pollination results also indicate the same and the fruit set rate is highest in open-pollinations, which are largely a function of foraging activity of bees. Despite high fruit set rate in this plant, its population size is small. Pollination among the individuals of this small population may lead to a reduction in genetic diversity and molecular studies on its genetic structure would enable to know the existing level of genetic variation. Transplanting the propagules from other mangrove forests, like mangrove of Mahanadi Delta of Orissa and the Sundarbans, to the study site would help to enhance gene flow in order to enable the plant to build up a stable and sustainable population size.

Seedling ecology. The flowers produce singled-ovuled ovary and the ovule invariably produces a single seed in fertilized flowers. This characteristic is advantageous for the plant to save and use the resources for higher fruit set rate. Seed is not dormant and produces hypocotyl within the fruit pericarp while still on the parent plant; it is a characteristic of cryptoviviparous species (Carey, 1934; Das and Ghose, 2003). The fruit with hypocotyl inside grows upward like the upwardly growing naked hypocotyl of $C$. decandra. Since the hypocotyl is concealed, the entire capsule-like fruit falls off when due for dispersal. Fruit pericarp is essential for the hypocotyl to float until it is settled. Self-planting and stranding strategies are functional for the dispersal of hypocotyls. But, field studies indicate that only a few of those hypocotyls which have fallen at the parental sites, settled well and showed further growth. Clarke and Kerrigan (2002) reported that the small-sized hypocotyls contain high nutrient content and low fibber content. The crabs prefer to consume such hypocotyls and feed on them prior to establishment. They also reported that $80 \%$ of the propagules failed to establish due to predation by crabs in Aegialitis annulata. Also, in the study site of A. rotundifolia, crabs are common and they may be consuming most of the hypocotyls prior to their establishment and hence, affecting the recruitment process of the plant. 


\section{CONCLUSIONS}

The sexual system and breeding systems functional in A. rotundifolia facilitate to produce fruit with or without vectors. Further, the crypto-vivipary, self-planting and stranding strategies enable it to survive and build populations in the mangrove forest. The plant is a potential nectar and pollen source for visiting bees. Therefore, the interactions between the plant and bees benefit both, the former for pollination and the latter for forage. 


\section{ACKNOWLEDGEMENTS}

We thank the Andhra University, Visakhapatnam, India, for providing facilities to carry out this research work. 


\section{REFERENCES}

1. Aksornkoae S., Maxwell G., Havanond S. and Panichsuko S., 1992 - Plants in Mangroves, Chalongrat Co., Ltd., Thailand, 120.

2. Aziz T. N. A. and Hashim N. R., 2011 - Heavy metal concentrations in an important mangrove palm (Nypa fruticans), in Rembau-Linggi Mangrove Forest (Peninsular Malaysia); Transylvanian Review of Systematical and Ecological Research, 12, The Wetlands Diversity, 111-116.

3. Baker H. and Baker I., 1973 - Some anthecological aspects of evolution of nectar-producing flowers, particularly amino acid production in nectar, in Taxonomy and Ecology, Heywood (ed.), Academic Press, London, 243-264.

4. Baker H. G. and Baker I., 1983 - A brief historical review of the chemistry of floral nectar, in The Biology of Nectaries, Bentley B. and Elias T. (eds), Columbia University Press, New York, 126-152.

5. Bhattacharya K., Majumdar M. R. and Bhattacharya S. G., 2006 - A Textbook of Palynology (Basic and Applied), New Central Book Agency (P) Ltd., Kolkata, 352.

6. Carey G., 1934 - Further investigations on the embryology of viviparous seeds, Proceedings of Linnean Society of New South Wales, 59, 392-410.

7. $\quad$ Chapman V. J., 1976 - Mangrove vegetation, Cramer, Valduz, Germany, 447.

8. Clarke P. J. and Kerrigan R. A., 2002 - The effects of seed predators on the recruitment of mangroves, The Journal of Ecology, 90, 726-736.

9. Cruden R. W., 1977 - Pollen-ovule ratios: a conservative indicator of breeding systems in flowering plants, Evolution, 31, 32-46.

10. Dafni A., Kevan P. G. and Husband B. C., 2005 - Practical Pollination Biology, Enviroquest Ltd., Ontario, 590.

11. Das S. and Ghose M., 2003 - Seed structure and germination pattern of some Indian mangroves with taxonomic relevance, Taiwania, 48, 287-298.

12. De Groot A. P., 1953 - Protein and amino acid requirements of the honey bee (Apis mellifera L.), Physiologia Comparata et Oecologia, 3, 197-285.

13. Harborne J. B., 1973 - Phytochemical Methods, Chapman and Hall, London, 288.

14. Hogarth P. J. 1999 - The Biology of Mangroves, Oxford University Press, Oxford, England, ISBN 0-19-850222-2.

15. Kathiresan K. and Bingham B. L., 2001 - Biology of mangroves and mangrove ecosystems, Advances in Marine Biology, 40, 81-251.

16. Lowry O. H., Rosebrough N. J., Farr A. L. and Randall R. J., 1951 - Protein measurement with the folin phenol reagent, The Journal of Biological Chemistry, 193, 265-275.

17. Naskar K. and Mandal R., 1999 - Ecology and biodiversity of Indian Mangroves, Part I, Global Status, Daya Publishing House, New Delhi, 783.

18. Opler P. A., 1983 - Nectar production in a tropical ecosystem, in The Biology of Nectaries, Bentley B. and Elias T. (eds), Columbia University Press, Columbia, 30-79.

19. Qureshi M. T., 1993 - Rehabilitation and management of mangrove forests of Pakistan, in Towards the Rational Use of High Salinity Tolerant Plants, 1, Leith H. and Al Masoom A. (eds), Kluwer Academic Publishers, The Netherlands, 89-95.

20. Ramasubramanian R., Ravishankar T. and Sridhar D., 2003 - Mangroves of Andhra Pradesh. Identification and Conservation Manual, M. S. Swaminathan Research Foundation, Chennai, 48.

21. Scholander P. F., 1968 - How mangroves desalinate water, Physiologia Plantarum, 21, 251261.

22. Tomlinson P. B., 1986 - The Botany of Mangroves, Cambridge University Press, New York, 413. 
23. Weber-El Ghobary M. O., 1984 - The systematic relationships of Aegialitis (Plumbaginaceae) as revealed by pollen morphology, Plant Systematics and Evolution, 144, 53-58. 